Colloquia Litteraria

UKSW

$2 / 2015$

ALEKSANDRA PAWLIK-KOPEK

\title{
DOM JAKO FIGURA ARTYSTYCZNA W POEZJI TERESY FERENC. WSTĘP DO PROBLEMATYKI
}

Twórczość Teresy Ferenc, nawiązując do autentycznych wydarzeń wojennych, stanowi poetycką próbę ujęcia tragicznych doświadczeń tego okresu. Autorka w wieku dziewięciu lat przeżyła hitlerowską pacyfikację rodzinnej wsi Sochy (1943), w czasie której zamordowano większość mieszkańców, również jej rodziców ${ }^{1}$. Stąd też znakiem utraconego dzieciństwa i symbolem wartości rodzinnych, a równocześnie jedną z najważniejszych figur artystycznych jest w twórczości poetki - dom. Podwójnie umocowany w świecie przedstawionym jako element przestrzenny i ontyczny, staje się miejscem doświadczania i bytem doświadczającym.

Dom w poezji Teresy Ferenc nie stanowi zatem jedynie pretekstu do poetyckiej refleksji, nie jest tylko kontekstem wydarzeń tekstowych, wreszcie - nie pełni podrzędnej roli w stosunku do podmiotu czy bohaterów wierszy. Dlatego trudno zgodzić się ze słowami Krzysztofa Nowickiego, który w niewątpliwie ciekawym wstępie do zbioru Cztery twarze domu. Antologia rodzinna zaznaczał:

[...] w wypalonej dolinie bije najczystsze źródło wyobraźni [poetki]. Zatem wynika ono z b r a k u domu, z jego pożaru, unicestwienia ${ }^{2}$.

1 Por. Nota o autorce, w: Teresa Ferenc, Ogniopis. Wybór wierszy, Warszawa 2009, S. 222-223.

${ }^{2}$ Krzysztof Nowicki, Dom poezji, w: Teresa Ferenc, Anna Janko, Zbigniew Jankowski, Milena Wieczorek, Cztery twarze domu. Antologia rodzinna, Szczecin 1991, s. 9. 
Źródła poezji Ferenc można, owszem, upatrywać w dolinie, ale nie wypalonej. Obraz matki, głębokie relacje rodzinne i silne zasady moralne są tymi jakościami, które dolinę tę współtworzą; jest ona azylem, przestrzenią najbardziej własną i pewną. Gdyby poezja ta miała inne źródła, gdyby jej podstawą było unicestwienie, a nie pamięć bezpiecznego schronienia, to zatrzymałaby się ona jedynie na tragicznych wydarzeniach, nie wyszłaby poza świat naznaczony zagładą. A przecież poetka kolejnymi wierszami zaświadcza, że obecna w nich figura domu ciągle trwa - mimo dramatycznych losów jego mieszkańców, na przekór płomieniom. W tej perspektywie ważny staje się nietytułowany utwór $\mathrm{z}$ debiutanckiego tomu Ferenc:

Przepadły tego lata czułość i ciepło [...]

Strzaskane ptactwo wyfrunęło, miażdżąc szyby niebieskości.

O tej porze muzyka srebrzy zbożem, w kłosach lato zaczyna się chwiać.

I nie wiadomo co lżejsze, sypki piach czy płacz.

Mam waszą młodość na drogę i miłość.

Mam resztę po was ogromną

$$
\dot{Z} y c i e^{3} \text {. }
$$

Należy podkreślić, że przywołany wiersz został usytuowany w szczególnym miejscu tomu. Poprzedza go cykl Moje ryżowe poletko, którego utwory wyrażają afirmację życia; jest też ostatnim wierszem cyklu Modlitwa za bliskich, składającego się z tekstów poświęconych

\footnotetext{
3 Teresa Ferenc, [Przepadły tego lata...], w: tejże, Moje ryżowe poletko, Katowice 1964, s. 32.
} 
zmarłym rodzicom; jednocześnie występuje przed cyklami: Dziadek, Poród i Wino, których tematyka koncentruje się na sprawie istnienia. Lokalizacja ta nie jest chyba nieprzypadkowa. Słowa bohaterki bowiem z jednej strony są pożegnaniem, z drugiej zaś sugerują otwarcie kolejnego etapu i zwrócenie się ku nowemu. „Młodość”, „miłość” i „życie” stają się tym, co dane przez rodziców, ale także - $\mathrm{z}$ a d a n e przez nich i orientujące podmiot na przyszłość. Dlatego tak ważna w utworach poetki jest figura matki, uświęcającej dom swoją miłością i swoim cierpieniem, co jest doskonale widoczne chociażby w wierszu Matka z płatkiem ognia: „Matko fajerka zsunięta / garnek leci z pieca / do żywego wykrzyczą / ten dzień twoje dzieci"*, czy w utworze Dziecięca Madonna: „Złotym liściem powleka się dom / złote liście głodne jak otchłań [...] / Błogosław szepcze żywa jeszcze matka”.

W wierszu [Przepadły tego lata...] jawna aluzja do domu („Strzaskane ptactwo wyfrunęło, / miażdżąc szyby niebieskości”) ukazuje w perspektywie wertykalnej moment zniszczenia jednolitej do tej pory struktury budynku, sam dom nie przestaje jednak istnieć. Wymowę tego obrazu cechuje więc pewna „podwójność. Wyfruwające ptactwo, owszem, konotuje okaleczenie i brutalność, ale także siłę, wyzwalający ruch ku wolności. Podobny motyw wzlatującego ptaka pojawia się między innymi w wierszu Wieś skamieniała: „Wyparowuje anioł znad kołyski / zrywają się ptaki ze ścian / święty Franciszek im sufit otwiera”, oraz w utworze Wniebogłosy: „Ptak wyrwał skrzydło z powietrza / Drzewo zieleń podniosło z prochu / Spojrzałam w okno"7. Istnieje zatem w poezji Teresy Ferenc transparentna granica między niebem jako synonimem życia wiecznego oraz ziemią - miejscem często naznaczonym cierpieniem, okrucieństwem i śmiercią. Warto podkreślić, że podział ten wyznaczają wielokrotnie

\footnotetext{
4 Teresa Ferenc, Matka z płatkiem ognia, w: tejże, Pieta, Gdańsk 1981, s. 26.

5 Teresa Ferenc, Dziecięca Madonna, w: tejże, Boże pole. Wiersze nowe 1988-1996, Poznań 1997, s. 20.

6 Teresa Ferenc, Wieś skamieniała, w: tejże, Wypalona dolina, Warszawa 1979, s. 10.

7 Teresa Ferenc, Wniebogłosy, w: tejże, Pieta, dz.cyt., s. 34 .
} 
„szyba” i „próg” - punkty graniczne, bezpośrednio odsyłające do semantyki związanej ze słowem „dom”, który staje się miejscem, prowadzącym do innej rzeczywistości. Samo przejście jednak często wiąże się dla człowieka ze zranieniem i bólem. Przestąpienie strefy dzielącej oba światy łączy się w wierszu [Przepadły tego lata...] z wizją tego, co pozostaje przy ziemi, ze światem fragmentarycznym, który mimo swych ran zachowuje solidną podstawę, wyznaczającą dalszą drogę. Zatem przekroczenie granicy nie oznacza jedynie, że objęci będziemy perspektywą wertykalną, kodowaną w metaforze ruchu ptaków i kierującą ku wieczności, ale wskazuje również na obecność perspektywy horyzontalnej, widocznej w obrazie drogi prowadzącej w stronę ziemskiej egzystencji.

Mimo że można odnieść wrażenie, iż dom w poezji Teresy Ferenc jest kształtowany przez symbolikę pożaru i spopielenia (np. wiersze: Matka płonaca z tomu Wypalona dolina, Płonacy dom ze zbioru Pieta, czy W skrzydłach ognia z tomu Grzeszny pacierz), to wizja ta ostatecznie świadczy jednak o tęsknocie za domem - miejscem s p r z e d tragedii. Zatem dom-gruzowisko to obraz wtórny. Niewątpliwie ciekawą realizacją tego motywu jest dom, który poetka ukazuje w wierszach traktujących o miejscu, tworzonym przez bohaterkę na podstawie wspomnienia o poprzednim domostwie, centrum szczęśliwego życia rodzinnego. W wierszu z tomu Godność natury czytamy:

$\mathrm{W}$ domu

często tak pustym

że słychać tykwę dzwoniącą

ziarnem

chodzę jak mysz

gryzę język żeby się nie powtarzać

chowam się żeby się wam dochować

w swej ślepej miłości

której trzeba po ludzku

przywracać wzrok

czułość ważyć

odchodzić w porę 
i wracać na czas

znać smak i mądrość kłamstwa

$\mathrm{w}$ domu

który się wysiewa ${ }^{8}$.

„Dochodzenie” do domu jest dla bohaterek wierszy Ferenc procesem trudnym i złożonym. To niejednokrotnie żmudna praca, przekraczanie siebie, a zdarza się, że postępowanie wbrew sobie. Już w pierwszej strofie cytowanego utworu metafora tykwy uruchamia jej kontekst kulturowy. Jako roślina święta według wielu mitów istniała jeszcze przed powstaniem świata i, jak pisał Henryk Jurkowski, służyła bogom do jego tworzenia'. Badacz cytował za autorami książki Marionnettes et Masques au Coeur du Théâtre Africain:

Poza swymi możliwościami plastycznymi tykwa posiada niezwykłą symbolikę, którą przekazuje efektownie, gdy posiada kształt lalki. I tak wypełniona nasionami reprezentuje macicę kobiety ciężarnej: rozrzucone po całym świecie, nasiona te przyczyniły się do narodzin rodzaju ludzkiego. Służą jako naczynia rytualne w ucztach ofiarowanych przodkom. Rozbija się ją, by potwierdzić przymierze, załatwić sprawę, zakończyć rytuał pogrzebowy. W niezliczonych opowieściach tykwa pojawia się jako niezwykle silny przedmiot magiczny ${ }^{10}$.

Zatem „dom, który się wysiewa” - łączony z tykwą - nasuwa skojarzenie z porodem, wydawaniem z s i e bi e życia. Obok motywu macierzyństwa pojawia się w tym obrazie istotny element mitu kosmogonicznego i tym samym odwołanie do "początku domu” (analogicznie do „początku świata”) jako głównego ośrodka tej poezji, miejsca, w którym mają swoje źródło kolejne fragmenty świata

\footnotetext{
8 Teresa Ferenc, W domu, w: tejże, Godność natury, Poznań 1973, s. 12.

9 Zob. Henryk Jurkowski, Materiał jako wehikuł treści rytuału, posł. Mateusz Kanabrodzki, Warszawa 2011, s. 157.

10 Olenka Darkowska-Nidzgorska, Denis Nidzgorski, Marionnettes et Masques au Coeur du Théâtre Africain, Charleville-Mézières 1998, s. 33, cyt. za: Henryk Jurkowski, dz.cyt., s. 158.
} 
przedstawionego. Osobność i „samotworzenie się” domu nie mogą jednak być tożsame z brakiem punktu odniesienia w przeszłości. Kluczowa jest tu metafora myszy. Kojarzona z płodnością i przetrwaniem w wierszu odsyła także do roztropności i ostrożnego działania. Przy czym mały rozmiar zwierzęcia, będąc znakiem płochości i nikłości, kontrastuje z przytłaczającym wymiarem przebytych doświadczeńn ${ }^{11}$ oraz odkrywa ciężar minionych wydarzeń.

Pomimo że „ważenie czułości”, „odchodzenie w porę” czy „wracanie na czas" nie są łatwe, to stają się konieczne, by zezwolić sobie na przyszłość. Trzeba więc nauczyć się dyscypliny, wziąć siebie w ryzy, żeby nie naruszyć ustanawiającego się porządku powstającego domu $^{12}$. Dzięki tym zabiegom, chociaż dom bywa pusty, to ciągle trwa. $\mathrm{W}$ tej perspektywie ziarna dzwoniące $\mathrm{w}$ tykwie świadczą o przyszłym

11 Podobny motyw można odnaleźć w wierszu Barbary Sadowskiej, w którym figura myszy także denotuje status podmiotu w obliczu zmagań mających związek z bolesną przeszłością. Utwór [dzięki Ci Boże, że mi rozum odjęło...] można również odczytywać przez pryzmat biografii autorki i wydarzeń związanych z zabójstwem jej jedynego syna Grzegorza Przemyka:

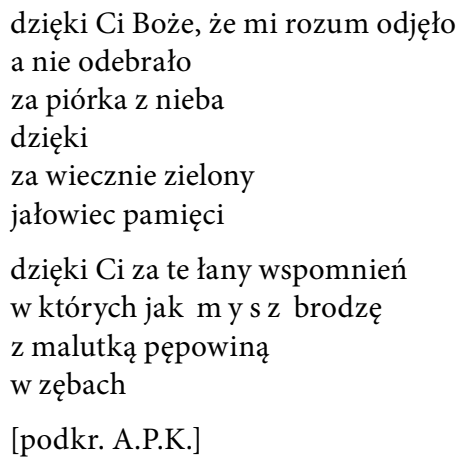

Barbara Sadowska, [dzięki Ci boże, że mi rozum odjęto...], w: tejże, Otwarte niebo, wieczny sen, wstępem opatrzył Jan Twardowski, wyboru dokonała Magdalena Koperska, Warszawa 1997, s. 188.

${ }^{12}$ Nie jest to jedyny utwór Ferenc w zbiorze Godność natury, w którym pojawia się słowo „siać". Sianie stanowi w tej poezji naturalną czynność, następującą po dramatycznych doświadczeniach podmiotu. Wyraża także nowy początek, którego 
plonie, a metafory związane z ziemią przywołują na myśl stabilność, spokój i bezpieczeństwo.

Bohaterki wierszy Teresy Ferenc posiadają podobne doświadczenia. Także miejsce, jakim jest dom, podlega dynamicznym przemianom, ale od początku warunkują je konkretne wydarzenia przeszłości. Jedną z głównych determinant tej poezji jest więc niezłomna postawa podmiotu, objawiająca się w procesie odbudowy domu:

Dziewczynka

w szczelinach domu

ukorzeniona ostrożnie

by nie popękał żywy jeszcze mur

lepiła następne piętra $\mathrm{z}$ ptasiej gliny

zaglądając w okna nieba

Którejś nocy szepnęła

ściągnę jasny obrus z Bożego stołu

osłonię dom pełen wiecznego odlotu

Schowam go

źródło leży jednak często w przeszłości. W wierszu Dzban ziemi, poruszając problematykę domu, autorka pisała:

Jeżeliś jeszcze niedaleko

jeżeliś nie zaszedł po zachód

zawróć drogę

niech się po drodze

w mój dom rozkrzewi

$[\ldots]$

Tu wrosłam

Tu na pniu jak niemowa

milczenie sieję

Dzban ziemi przyniosłam

Spełniony ciało rozwiąże

[podkr. A.P.K.]

Teresa Ferenc, Dzban ziemi, w: tejże, Godność natury, dz.cyt., s. 76. 
przed oczodołami zimnego wiatru

ząb czasu nie zeskrobie

skóry ze ścian

Już wiedziała

poprzez wieczność

trąby jerychońskie dmą ${ }^{13}$.

W wielu utworach Teresy Ferenc pojawia się dziewięciolatka, którą na stałe naznaczyły tragiczne przeżycia wojenne. Konsekwencją tych wydarzeń jest „zawieszenie” podmiotu między przeszłością i teraźniejszością oraz ostateczne związanie jego statusu ontycznego z figurą domu.

Cytowany wyżej utwór otwiera ósmy tom poetki - Pieta, który ukazał się po zbiorze Wypalona dolina. Jacek Łukasiewicz podkreślał, że to właśnie na kartach Wypalonej doliny poetka w sposób tak bezpośredni odniosła się do doświadczeń wojennych. Okazuje się zatem, że temat domu, scalający wiersze zbioru wydanego w 1979 roku, został podjęty, ale bynajmniej nie zamknięty, a raz naruszona struktura domostwa nie pozwala o sobie zapomnieć i domaga się ciągłego udziału podmiotu w odbudowie zniszczeń ${ }^{14}$.

W pierwszych wersach wiersza uwagę zwraca cierpliwość i delikatność w działaniu bohaterki. Wydają się one konieczne, by na miejscu tak obolałym „lepić następne piętra”. Akt twórczy nie polega w tej poezji na wielkich gestach, nie jest porywający ani spektakularny. To wysiłek „kopania”, „klejenia” i „lepienia”, łączony z pierwotną potrzebą, by skonstruować schronienie. Jego budulcem nie są wytwory człowieka, lecz surowce naturalne, takie jak glina (Dziewczynka buduje dom), rośliny (Dom ze zbioru Ciało i płomień) czy ślina (Psalm o szczéśliwej z Wypalonej doliny), co świadczy o tym, że bohaterka odnajduje bezpieczeństwo nie w cywilizacji, ale w naturze. Trudno jednak rozstrzygnąć, co kieruje tą potrzebą kreacji - tylko świadome

\footnotetext{
13 Teresa Ferenc, Dziewczynka buduje dom, w: tejże, Pieta, dz.cyt., s. 7.

14 Zob. Jacek Łukasiewicz, O poezji Teresy Ferenc, w: Teresa Ferenc, Widok na $\dot{z} y c i e$, Sopot 2012, s. 5 .
} 
poszukiwanie nowego domostwa czy także instynkt, jakim wiedzione są małe zwierzęta (ptak, mysz), będące metaforą chowania się, ukrycia.

Dom stanowi w tej poezji jedną z rzeczy pi e r ws zych, rozumianych jako fundamentalne punkty odniesienia dla egzystencji, i tej egzystencji gwarant. Jest więc nie tylko budynkiem w sensie przestrzennym, ale przede wszystkim miejscem bezpiecznym; dającym pewność, że granica między tym, co wewnętrzne i własne, a tym, co zewnętrzne i obce, nie zostanie brutalnie przekroczona. Ciągły proces budowania domu staje się w poezji Teresy Ferenc najważniejszym celem i podstawową wartością, ponieważ tylko „stabilny” dom pozwoli na podtrzymywanie pamięci o bliskich, którzy odeszli, i pozwoli tym obecnym na określenie swej tożsamości poprzez zajęcie miejsca w przestrzeni świata przedstawionego.

Podmiot wiersza Dziewczynka buduje dom nie jest słaby, to dom wydaje się konstrukcją kruchą i niepewną. Dopiero „ukorzenienie” dziewczynki (poprzez odniesienia do symboliki roślinnej) zrodzi siłę i pęd ku życiu, wprawdzie zaledwie powstającemu, ale łączonemu z nadzieją. „Żywy jeszcze mur” staje się metaforą domu czującego, żywej tkanki, która współtworzy jeden organizm $z$ jego mieszkańcami, nieżyjącymi, ale ciągle obecnymi („ząb czasu nie zeskrobie / skóry ze ścian”). Jednak wraz z rozrastaniem się rośliny pierwotna struktura muru ulegnie zmianie. Roślina będzie wzrastać, a mur powoli będzie kruszał. Stąd wprowadzony do wiersza obraz biblijnych trąb jerychońskich, przywołujący kontekst ziemi obiecanej, z jednej strony odnosi się do zniszczenia muru, ale z drugiej - niesie perspektywę przyszłego zwycięstwa i chwały. W poezji Ferenc wiążą się one z koncepcją rodziny. W utworze Dom na oddechu z tomu Ciało i płomień pisała:

Dom z krwi i ciała nie opuszcza mnie krzycząca podłoga wołająca ściana 


\begin{abstract}
drzwi skrzypią z braku
kropli krwi w zawiasach

ramy w oknach się paczą

w naczynkach krwionośnych

zachłysnęłam się

nadmierną suszą po ulewie

Jak komórka dzieli się dom

pączkuje jak drożdże

Wczoraj oddzieliła się córka ${ }^{15}$
\end{abstract}

Maria Dąbrowska-Czoch w artykule poświęconym korespondencji utworów Teresy Ferenc i Zbigniewa Jankowskiego zwracała uwagę, że w samym tytule cytowanego wiersza jest pewna wieloznaczność. Dom na oddechu, jak podkreślała, można odnieść do popularnego motywu „domu na wzgórzu”, ale także do parafrazy biblijnego „domu na skale” i „domu na piasku”, mając jednak ciągle na uwadze kontekst samego oddechu jako aktu ulotnego, efemerycznego, nawiązującego do ducha oraz duszy ${ }^{16}$. Badaczka, konkludując, pisała: „Dom byłby więc u Ferenc gmachem opartym na życiu w jego najszerszym rozumieniu" ${ }^{\prime 17}$. Opinia ta staje się szczególnie ważna w perspektywie ostatniej strofy utworu. Poza wcześniejszym wskazaniem na dom jako miejsce-organizm, które cieleśnie doświadcza rzeczywistości, pojawia się w wierszu wyraźne nawiązanie do domu jako miejsca cudu narodzin. Przy czym nie jest to wyłącznie zabieg metonimiczny, polegający na przeniesieniu obrazu rodzącej kobiety na dom. Antropomorfizacja przestrzeni to tylko początkowy etap pracy nad kształtowaniem autonomii domu, gdyż nie pełni on już służebnej roli egzemplum. Dlatego wydarzenia, które dotykają podmiot, w równym stopniu doświadczają także dom - kolejnego bohatera utworu. Na problem

\footnotetext{
15 Teresa Ferenc, Dom na oddechu, w: tejże, Ciało i płomień, Wrocław 1974, s. 29.

16 Zob. Maria Dąbrowska-Czoch, Poezja w małżeństwie, małżeństwo w poezji (Teresa Ferenc i Zbigniew Jankowski), „Język - Szkoła - Religia” 2014, nr 1, s. 91-93. 17 Tamże, s. 92.
} 
ten zwracała uwagę Elżbieta Rybicka w kontekście miejsca oraz jego „wydarzeniowości” i „idiolokalności”, o których pisał Edward Casey:

[...] doświadczeniem wydarzeniowości miejsca staje się także taki rodzaj poezji lub szerzej, twórczości literackiej, który rezygnuje z relacji „właścicielskiej” (ufundowanej na rozporządzalności miejsc i jedynie ludzkiej sprawczości) na rzecz relacji opartej na świadczeniu/świadkowaniu jego jednostkowości. Zapożyczając się dalej u Caseya, można by ten rodzaj pisarstwa nazwać li t e r a t u rą i d i ol ok a l n ości. Jej cechą szczególną jest precyzyjna lokalizacja, związana z konkretnym miejscem, różni się ona jednak od tradycyjnej liryki opisowej czy prozy topograficznej. Literatura idiolokalności jest bowiem nie tyle domeną deskrypcji, hypotypozy, ile dra matyzacją dośw i a d c zenia mi ejs ca. Dramatyzacją, ponieważ zarówno „ja” doświadczające, jak i doświadczane miejsce grają aktywne role. Miejsce nie jest tu tylko sceną ludzkiego dramatu, jest działającym i nieprzewidywalnym aktorem. Miejsca - ujęte w ich idiolokalności wprowadzają w ruch pamięci (autobiograficznej i kulturowej), ruch wyobraźni, także językowej, ale przede wszystkim oddziaływają na swój specyficzny, niepozwalający się zracjonalizować sposób ${ }^{18}$.

W świetle powyższych słów należy zaznaczyć, że dom w poezji Teresy Ferenc nie jest już tylko znakiem przeszłości oraz miejscem zamieszkania rodziny. Wydaje się, że ze względu na dramatyczny los, który w jego przestrzeni spotkał mieszkańców, w swoim indywidualnym cierpieniu otrzymał status osobnej egzystencji. Nie znaczy to jednak, że stał się bytem zamkniętym, ponieważ - przekraczając materialność i otrzymując cielesność - współodczuwa, w sposób zmysłowy doznaje bólu w wymiarze, który w pełni zgłębić może tylko człowiek. Jako żywy organizm zmienia się, także niszczeje, ale, zgodnie z filozofią życia poetki, podlegając procesom biologicznym, transcenduje tragizm śmierci. Będąc częścią całości, z której wszystko się wydziela, jedni - złożonej z konglomeratu tego, co ożywione i co przynależące do świata rzeczy, wydaje z siebie nowe istnienie.

18 Elżbieta Rybicka, Geopoetyka. Przestrzeń i miejsce we współczesnych teoriach i praktykach literackich, Kraków 2014, s. 184-185. Podkr. E/R/ 
Dom w tej twórczości niewątpliwie można definiować z perspektywy „miejsca” jako kategorii zainteresowania geopoetyki. Należy jednak podkreślić, że artystyczną figurę domu w poezji Ferenc kształtują dwa porządki. Z jednej strony bezpośrednio nawiązuje on do realnych wydarzeń roku 1943 - stąd Sochy, rodzinna wieś poetki, określają jego historyczność i konkretyzują go. Z drugiej strony - jest miejscem symbolicznym, sferą wertykalnie pojętej drogi z ziemi ku niebu. Budują go dwa toposy: locus amoenus i locus horribilis. Ta antynomiczność sprawia, że dom, w zależności od ujęcia, jest pars pro toto strasznego losu jego mieszkańców, a także wszystkich mieszkańców zniszczonej wsi, kraju, świata, i jednocześnie metaforą niepohamowanego pędu $\mathrm{ku}$ istnieniu, odradzania się życia, jego odnowy. Zatem jest to miejsce, w którym prywatność zakorzeniona w tradycji ukazuje uniwersum, inaczej mówiąc: to, co osobiście doświadczone, stanowi za sprawą poezji część wspólnej pamięci. Granicę prywatności wyznaczają więc w wierszach poetki trzy czynniki: przeżyte krzyżuje się z wyobraźnią poetycką i z tym, co rozumiemy przez szeroko pojętą kulturę oraz tradycję literacką ${ }^{19}$. Dom jako miejsce autobiograficzne ${ }^{20}$ staje się utraconą krainą szczęśliwości, która jednak, odbudowywana często $\mathrm{z}$ mozołem, na powrót funkcjonuje w teraźniejszości i daje nadzieję na przyszłość.

\section{Summary \\ Home as Artistic Figure in Teresa Ferenc's Poetry. A Critical Introduction to the Issue}

The article tentatively identifies issues regarding home as artistic figure in Teresa Fernenc's poetry. To indicate how home consists of two topoi, locus amoenus and locus horribilis, the author, for example, uses the tools worked out by the geopoetics field. Home appears to be a place formed as a result

\footnotetext{
19 Por. tamże, s. 173.

20 Zob. Małgorzata Czermińska, Miejsca autobiograficzne. Propozycja w ramach geopoetyki, „Teksty Drugie” 2011, nr 5, s. 183-194.
} 
of authentic experience of Ferenc as well as a symbol of the wartime fate of its inhabitants, in addition to symbolizing the restoration of the original order, which holds crucial importance for the ontological status of the subject in the writer's works. Home, understood in these terms, crystalizes as individual experience, poetic imagination, and literary and cultural inspirations of the poet.

Aleksandra Pawlik-Kopek (Katolicki Uniwersytet Lubelski Jana Pawła II) doktorantka w Katedrze Krytyki Literackiej KUL; jej główne zainteresowania badawcze to: poezja współczesna, krytyka literacka oraz związki literatury z filozofią i antropologią kultury. 